\title{
XLV. Description of the different methods of blowing up rocks under water
}

\section{A. Baillet}

To cite this article: A. Baillet (1802) XLV. Description of the different methods of blowing up rocks under water , Philosophical Magazine Series 1, 13:51, 268-273, DOI: $10.1080 / 14786440208676126$

To link to this article: http://dx.doi.org/10.1080/14786440208676126

Published online: 18 May 2009.

Submit your article to this journal $₫$

Џll Article views: 2

Q View related articles $ᄃ$ 
fideration of the Imperial Parliament, which, after examining various documents, and hearing the teftimony of feveral profeffional men of the firft eminence, acknowledged the value of the difcovery by voting a reward of 10,000 l. to Dr. Jenner.

XLV. Defcription of the different Metbods of blowing up Rocks under Water. By A. BAILLET, Injpector of Mines*.

Ift, $\mathrm{TE}$ operation of blowing up rocks, which the French call tirage des mines, is not in general attended with much difficulty, when the hole of the mine is pierced in dry compact ground without any fiffure or cavity. When the ground is cavernous or hollow, or when water oozes through its pores, it becomes more troublefome, and requires particular care. When it is neceffary to blow up rocks at the bottom of the water the difficulties are increafed. In that cafe the ufual proceffes muft be abandoned, and others mult be reforted to.

$2 \mathrm{~d}$, The method of blowing up rocks in the latter cafe is little known, and not much practifed : it may, however, be of great utility in many cafes, not only in the working of mines, but in the execution of public works of importance. Thefe motives have induced me to give a defcription of the three principal methods of blowing up mines under water.

The firt is that ufed in the mines in the northern part of the republic: it is proper to be reforted to when the depth of the water which covers the ground intended to be blown up is not above 15 or 18 decimetres.

The fecond has a great refemblànce to the procefs ufual in mines when the ground fuffers the water to ooze through it. It is fimpler and lefs expenfive than the preceding, and appears to me to be very proper for cafes when there are only a few decimetres of water above the ground.

The third is fuited to great depths of water, fuch as 4, 5, or 6 metres: it is that employed at Carlfcrona. It is very ingenious, and feems hitherto to have been unknown to the French miners.

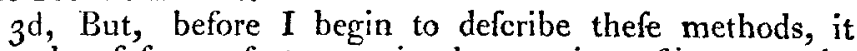
may be of fome ufe to mention here an interefting memoir, printed in the Journal de Phyfique for the year 1779, on the conftruction of air-boats proper for facilitating the execution of all forts of works under water, without employing pump-

* Froin the Fournal des Mines, No. 56 . 
ing. C. Coulomb, the author of this memoir, after defcribing the method of conftructing the air-boat, fhows in what manner it is to be uled. He points out the means by which it may be made to fink at pleafure, of placing the workmen under the box, of continually renewing the air, of removing the rubbith and loving a foundation of mafon-work at the bottum of deep water. He then calculates the time neceffary for removing a metre in height from the bank of Quillebueuf, which interrupts the navigation of the Seine; and forefering the cafes in which mattocks or pick-axes would be infufficient for clearing obftructions from the bottom of the water, and where the hardnefs of the rock might require the ufe of gun-powder, he propofes two methods of blowing up rocks under water.

In one, the workman placed under the box bores the rock, and introduces into the bottom of the hole a box of tin plate filled with gun-powder, to which is foldered a fmall tube, alfo of tin plate, which rifes above the water at ebb-tides, and which is ftopped with fome greafy matter, after having been filled with a very weak compofition to ferve as a train. The fea, as it rifes, makes the air-boat float; and when its lower edge has rifen higher than the extremity of the tube it is then removed, and when the ebb-tide uncovers that extremity a perfon goes in a boat and fets fire to it.

In the other method, which the author propofes for the Mediterranean, and rivers where the affiftance of the tide cannot be employed, the tube of tin plate which contains the train rifes only 3 decimetres above the rock, but is terminated by a leather pipe covered on the outfide with fome water-proof fubftance, and in the infide with an incombuttible varnith, and fecured from the preffure of the water by a piral winding made of wire. Its extremity muft be carefully clofed, and a buoy attached to it carries it to the furface of the water when the air-boat is afloat.

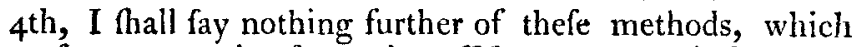
fuppofe, as may be feen, the affiftance of the air-boat. I only withed to point them out, becaufe they may be ufeful in many cafes, and may, befides, give rife to new ideas, and ferve to modify the three particular methods which are the object of this memoir.

\section{Metbod of blowing up Recks at the Deptb of 15 or 18 Cen- timetres under Water.}

$5^{\text {th }}$, This method confifts in the following operations;

Firlt, bore the hole at the bottom of the water by the help of borers, and inftruments of proper length. 
Then place in the hole a tube of tin plate clofed at the lower extremity. The exterior diameter of this tube is of fuch a fize that, when introduced into the bore, it may fill it ; and its length muft be fuch as that it fhall rife fome centimetres above the furface of the water.

Then fend down to the bottom of this tube the cartridge filled with powder; introduce the priming rod, and ram round it clay or plafter according to the ufual procels, and only to the height correfponding to the fummit of the hole.

In the laft place, draw the priming rod and introduce the train, and fet fire to it with all the neceffary precautions, that the workmen may be theltered from danger at the time of explofion.

\section{Obfervation.}

6th, This method has been often employed with advantage in feveral mines of the republic : it may ferve either for deepening wells, or making other excavations, when the means ufed for keeping the ground and bottom of wells conftantly dry are infufficient.

\section{Metbod propofed for blowing up Rocks fome Decimetres below Water.}

7 th, When the ground or rock to be blown up is covered only by fome decimetres of water, the miner can fee the rock which he bores, and the hole to be loaded, with as much eafe as if there were no water, and can work with the fame facility. In this cafe, to fave expenfe, the tube of tin plate may be omitted, and a cartridge of pitched cloth, fuch as that employed in ground through which the water oozes in every part, may be employed, adapting to it a rod of hollow wood * deftined to contain the train that conveys the fire to the powder. The diameter of the aperture of this rod may be only a few millimetres, and its length muft exceed the upper level by tome centimetres.

8 th, If this method be adopted, firft conftruct a cylindric cartridge of cloth or pafteboard, and fill it with gunpowder; infert into it the rod, which muft defcend to the midale of the length of the cartridge without approaching the interior furface of the wrapper; pinch clofely the upper part of the cartridge around the rod, and cover the cartridge and whole rod with pitch or fome kind of varnilht. Then fend down the cartridge furnithed with its rod into the hole of the rock,

* This rod might be made of the elder or honeyfuckle.

+ A tolution of Spanith wax in alcohol is attended with the advantage of diyng tpeedily, ard of remaining water-proof for a long time. 
and drive in ftrongly two plugs of dry wend to ferve as wadding. Theie plugs mut have a longitudinal groove, that they may glide along the rod and fuifer the water to efcape.

\section{Obfervation.}

$9^{\text {th }}$ Inftead of a rod of hollow wood you may employ, with advantage, either a tube of tin plate about four millinetres in diameter, terminating at the lower extremity, which natit be inferted in the cartridge in a truncated cone, and an oritice of two millumetres; or a leaden pipe drawn in the manner of wire.drawers, having the fame dimenfions as the abure, and whofe refiftance may be fufficient, if you take care to introduce into it, while you drive in the wadding, a rod a hich may exactly fill the interior vacuity.

If you have at hand any kind of compofition capable of arquiring hardnefs in a little time * at the bottom of the water, you may fubititute for the rod and metallic tubes a flexible tube of clolb done over with pitch or gum. In this cafe, it will be neceffary to introduce the priming rod into the tube, while you drive in the waddung to prevent its depreffion. The cloth of the tube, the upper extremity of which is deftined to rife above the hole in the rock, mult be fufficiently thick and trong that the preffure of the water, which I fuppofe to be fome centimetres above the ground, may not flatten it, even if the liquid thould introduce itfelf between the tube and the compofition.

\section{Metbod of blowing up Rocks under Water at any Deptb.}

roth, This method, on the firft view, has a refemblance to that firft deferibed, fince a tube of tin plate is employed in it; but it differs effentially from it in this refpect, that inftead of wadding above the charge, according to the ufual method, you employ an inflexible fhank charged with a weight at its upper extremity, and terminating at the lower in a fegment of an iron cylinder, which performs the office of a wedge, and is applied exactly upon another fimilar wedge inverted and refting on the upper end of the cartridge.

The effect of this difpofition, as may be readily conceived, is to force the wedge which adheres to the cartridge to afcend a little at the time of the explofion, and to fqueeze itfelf clofely againt the upper wedge fo as to clofe the hole in the rock.

IIth, The defcription of this procefs may be feen in the

; A mixture of quicklime and plafter newly calcined would, perhaps, be of this kind. 


\section{Different Metbods of blowing up Rocks under Water.}

twelfth volume of the Memoirs of the Academy of Stockholm; I thall therefore give a literal tranflation of it *

\section{New Metbod of blowing up Rocks under Water, by Daniel Tbunberg.}

A profile of the rock which has been bored, and into which the charge is introduced, is reprefented PI. V. fig. I.

The charge is contained in a tube of tin plate impermeable to water, a vertical fection of which is reprefented in the fame figure. The lower extremity of this tube muft be adjufted properly to the hole which has been bored in the rock.

The charge confifts of a paper cartridge filled with gunpowder, and attached to the iron wedge $b$ with a thread fuch as that ufed for fewing fails.

To this firft wedge $b$ is applied another $c$, which adheres to an iron rod that rifes above the tube.

On the plane face of thefe wedges is a groove made with a file which reaches to the powder: this groove is continued throughout the whole length of the tube of tin plate by means of a wooden rod $d$, hollow on the fide turned towards the iron rod, to which it is made faft with ftrong packthread.

Before this rod is attached to the iron one, a match, which proceeds from the upper extremity and communicates with the interior of the cartridge, is placed in the groove.

$e$ is a train applied to the end of the match.

$B, C$, are two rafts which enable the workmen to bore the rock and blow it up.

$\mathrm{D}$ is a weight which prevents the iron from being repelled too far when the explofion takes place.

E FGHI are different pieces neceffary for charging. $\mathbf{E}$ is the cartridge furnithed with its wedge, feen fideways; $F$ the wedge feen in front; $G$ the wooden rule and its groove; $H$ the upper wedge and its iron rod; I the tube of tin plate.

When the rock has been bored according to the ufual method by employing a borer pretty ftrong and of fuch a length as the depth of the water may require, introduce into it the tube into which the charge has been put; then apply the train $e$, and, having placed the weight $D$ above the rod; fet fire to it. The explofion will immediately take place: the wedge $b$ would be expelled but for the wedge $c$, which cannot give way; and the two wedges being thus united confine the charge, the effect of which will never fail, as has been proved by experience.

* Details refpeeting this procefs may be found alfo in a large work cnsitled $D_{e f c r i p t i o n}$ des Travaux cuccutés à Carlfcrona, far Daniel Thunberg.

Four 
Four feet of the tube and the lower wedge are in general loft; but the upper wedge may be employed for new charges, becaufe it is never damaged.

\section{Objervation.}

12th, This method, the fuccefs of which is proved, deferves, no doubt, to be known by all thofe engaged in great undertakings, and who have frequent occafion to apply it *. It is, perhaps, fufceptible of being modified; and it appears to me that, without employing the impermeable tube, a varnifhed cartridge might be ufed, with a flexible tube proceeding from it, lodged in the groove between the two wedges, and then rifing above the water.

Fire alfo might be conveyed to the powder below the water by means of a frong difcharge of electricity; but little can be expected from this method in the hands of workmen.

In the laft place, the lower wedge might be made of hard and very dry wood.

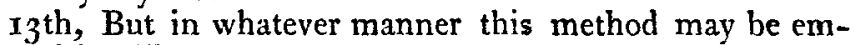
ployed it will not require great expenfe, and it may be ufed with great advantage for deepening ports, rendering certain harbours more convenient and fafe, and for freeing rivers and ftreams from thofe rocks which obftruct their courfe and impede the navigation of them.

XLVI. Account of a Nortb-Eaft Storm, or Memorandums towards a Theory of the Winds in the Region between the Gulf-Streäm and the Great Range of Mountains $\uparrow$.

$\mathrm{O}_{\mathrm{N}}$

$\mathrm{N}$ the Atlantic coaft of America north-eaft ftorms begin in the fouth-weft, and proceed thence to windward at the rate fometimes of about one hundred miles an hour. It has been remarked long ago by Dr. Franklin, that ftorms from the north-eaft, on the eaftern fide of this continent, begin in the oppofite point, or to leeward. Whether this rule univerfally obtains may perhaps as yet admit of fome doubt:

M. Daniel Thunberg employed the fame means to raife large blocks of ftone from the bottom of the water. For this purpofe a hole is bored in the block with a miner's borer to the depth of twenty or twenty-five centimetres. Two wedges are introduced into it, forming by their junction a cylinder fo as to fill the hole. Several blows are then fruck on the iron bar which adheres to the upper wedge: the two wedges are then clofely fqueezed together, and the block is raifed out of the water by means of a windlafs and a cord attached to a ring fixed in the lower wedge.

+ Communicated by Dr. Mitchill. 